MAATIE

MAGYAR AGRÁR- ÉS

ÉLETTUDOMÁNYI EGYETEM

www.columella.hu

Columella

\title{
Different organic mulch materials affect the abundance of enchytraeids in an open-field experiment
}

\author{
Renáta PETRIKOVSZKI ${ }^{1}$ - Fanni BÁRÁNYOS ${ }^{2}$ - Amelita Gerda MOLNÁR ${ }^{2}$ - Ferenc TÓTH ${ }^{2}$ \\ - Gergely BOROS ${ }^{2}$ \\ 1: Hungarian University of Agriculture and Life Sciences, Plant Protection Institute, Department of \\ Integrated Plant Protection, H-2100, Páter Károly u. 1., Gödöllő, Hungary, e-mail: petrencsi @ gmail.com \\ 2: Hungarian University of Agriculture and Life Sciences, Institute for Wildlife Management and Nature \\ Conservation, Department of Zoology and Ecology, H-2100, Páter Károly u. 1., Gödöllő, Hungary
}

\begin{abstract}
Organic mulch may provide favourable soil conditions e.g. soil moisture or organic matter content, which may enhance the number of enchytraeids. However, there is no sufficient information about the relationship between plant-based mulch and this beneficial soil animal group. Therefore, an open-field experiment was conducted with tomato as a test plant to examine the effect of different types of organic mulch materials on the natural occurence of enchytraeids. Our study microplots received the following treatments: 1) yard-waste compost, 2) walnut leaf litter, 3) mixed leaf litter without walnut and 4) wheat straw. Control microplots were left unmulched. Randomized block design was used with eight replications to the treatments and four to the control. At the end of the growing season, three soil samples were taken from the root zone of each plant with a split soil corer, and enchytraeids were extracted by the wet funnel method. Living enchytraeids were counted under a dissecting microscope, and their density values were estimated. Worms were identified in five randomly selected samples of each treatment. In addition, soil moisture was determined by oven-drying as well. Mulch material types had significantly different effects on both Enchytraeid density and soil moisture. Under walnut leaf litter, mixed leaf litter and straw cover, higher numbers of individuals were found. In the case of soil moisture content, straw mulching had the highest value, while compost and uncovered surfaces the lowest. It appears that mulch materials serve as food source and provide favourable conditions for enchytraeid communities as well.
\end{abstract}

Keywords: Annelids, compost, leaf litter, potworm, straw

Received 14 May 2020, Revised 29 October 2020, Accepted 24 November 2020

\section{Introduction}

The use of organic, plant-based materials as surface mulch has several positive effects: controlling weeds, enhancing root growing, increasing soil humus content by the decomposition of materials (Goulet et al. 2004, Pupalienè et al. 2015, Stefanovits et al. 1999). Mulching in general, helps to preserve soil moisture and prevents soil degradation (Adekalu et al. 2007, Pinamonti 1998). In addition, it can reduce the fluctuation of soil temperature (Pinamonti 1998).

Mulching has an effect not only on soil but on the fauna living within or on the sur- face of the soil. However, the efficacy of soil cover depends on mulch type and the casts of soil organisms. According to Addison et al. (2013), mulching may primarily increase the presence of omnivorous species. Straw and compost mulching may enhance the number of natural enemies and compost increased the abundance of soil macroinvertebrates (Thomson and Hoffman 2007). At the same time, fewer arthropod pests were found when straw, compost or woodchips mulch was used, compared to the unmulched control (Addison et al. 2013). Both leaf litter and hay mulch enhanced not only the total number, but the diversity of carabids (Dudás 
et al. 2016). Arthropods were found more diverse and abundant under black walnut leaves (Summers and Lussenhop 1976). Tea and flower compost enhanced the accumulation of free-living nematodes in mulched soil (Langat et al. 2008). Compared to the unmulched control, alfalfa hay mulch and vermicompost increased the density of bacterivore nematodes but decreased the presence of fungivore, predatory-omnivore and plantparasitic nematodes (Forge et al. 2003, Xiao et al. 2016). Rye straw decreased the number of root-knot nematodes, Meloidogyne graminicola on wheat roots (Kandel et al. 2011). However, green and yard-waste composts did not affect plant-parasitic nematodes (McSorley and Gallaher 1995). Jodaugienè et al. (2010) found that the density of earthworms was higher under straw and grass mulch, but it was not different when collected from unmulched control plots or from under peat or sawdust mulch. Black walnut leaves also decreased earthworm abundance (MacDaniels and Pinnow 1976).

Enchytraeids are considered to be ecosystem engineers with ants, earthworms and termites (Brussaard et al. 2012). Similar to earthworms, they are able to provide favourable conditions for microbial activity (Kasprzak 1982). According to Domínguez and Bedano (2016), enchytraeids and earthworms complement each other: in the rice-growing system, the drainage period would be more appropriate for earthworms, while enchytraeids would be more efficient during the very moist or flooded conditions (John et al. 2019). The role of enchytraeids in agroecosystems is essential: they can influence the aeration and permeability of soil for roots by their burrowing activity and they can also stabilize soil structure by their mucilages and excrements (Didden 1991). According to Didden (1991), organic farming, with the application of organic manure, cover crops, and the use of shallow soil work, favour enchytraeids.
Enchytraeids consume, beside other food sources, bacteria, fungi, mineral particles and leaf litter (van Vliet and Hendrix 2012) and choose old and decomposed leaves more frequently than fresh ones. However, their food preferences are different among species (Dózsa-Farkas 1976).

The connection between enchytraeids and different organic matters is contradictory: while Ricci et al. (2015) did not observe any positive change in the abundance of enchytraeids to the effect of animal manure and composted sludge, Andrén and Lagerlöf (1983) found that the addition of sludge and farmyard manure addition enhanced their numbers. Beside other soildwelling animals, enchytraeids as well may respond differently to various organic matters. The most frequent mulchers are organic farmers, who apply organic or inorganic mulch materials on the soil surface. Common organic mulch materials are compost, straw and wood chips (Dezsény 2015). Furthermore, a large amount of mulch material in the form of leaf litter is produced at defoliation in every autumn in Hungary. However, the use of this valuable organic matter is not sufficiently prevalent either in agriculture, or in horticulture. We aimed to examine the effect of four types of organic mulching materials (standard yard-waste compost, walnut leaf litter, mixed leaf litter and wheat straw) on enchytraeid communities in an open-field long-term experiment.

\section{Materials and Methods}

\section{Open-field experiment}

Study plots were established on the Experimental Field of the Department of Integrated Plant Protection of the Szent István University (Gödöllő, Hungary). The experiment was conducted during the growing season of 2019 with the Hungarian landrace tomato 'Dány' (RCAT057829) as crop plant.

Before our study, a long-term mulching ex- 
periment has been going on between 2016 and 2018 with potato ('Hópehely' and 'Démon') with the same mulching treatments and setup (Fehér et al. 2017, Südiné Fehér et al. 2019) in the same place.

The dominant soil type of the plots was coarse sand. We erected pinewood frames to separate treatments on the soil surface. Thus, we had 36 microplots, each measuring $2 \mathrm{~m} \times 2 \mathrm{~m}$ on a total area of $144 \mathrm{~m}^{2}$. In one microplot, four tomato plants were planted, giving an isolation distance of $1 \mathrm{~m}$ between plants. Microplots received the following treatments: 1) standard yard-waste compost ('Zöld Híd Komposzt' 04.2/32452/2017 Nébih 2020), 2) walnut (Juglans regia) leaf litter, 3) mixed leaf litter (without walnut), 4) wheat straw. Control microplots were left unmulched. Leaf litters were collected in Gödöllô after the fall of leaves in autumn of 2018. Mixed leaf litter contained the leaves of Acer spp., Aesculus hippocastanum, Castanea sativa, Corylus avellana, Platanus $\times$ acerifolia, Quercus spp., Salix spp., Sorbus spp. and Tilia spp. at the ratio of approximately $1: 1$. Compost material was provided by Zöld Híd B.I.G.G. Nonprofit Kft. (Gödöllő, Hungary), and straw was collected by a local farmer of Gödöllő (József Babarczi). In the case of mulching treatments, eight replications were used. In addition, there were four replications for the unmulched control. Replications were set in randomized block design (Figure 1). Mulch materials were spread in a $15 \mathrm{~cm}$-thick layer on 3 April 2019.

Plots has not received soil work since 2016. Tomatoes were planted into undisturbed soil on 28 May, and plots were hand-weeded or hoed every ten days during the growing season (Petrikovszki et al. 2020). After collecting soil samples, the experiment was terminated, and plants were removed.

\section{Data collection}

Enchytraeids were collected at the end of the growing season, 4 October 2019. Three soil samples were taken from the root zone of each plant with a split soil corer (diameter of $5 \mathrm{~cm}$ ) to $10 \mathrm{~cm}$ depth (volume approximately $200 \mathrm{~cm}^{3}$ per sample), mixed and then a single aliquot with the volume of $200 \mathrm{~cm}^{3}$ was taken for worm extraction by wet funnel method (O'Connor 1962). Living enchytraeid individuals were counted under a dissecting microscope (Olympus SZ-60, × 10$\times 20$ ). In five randomly selected samples of each treatment, worms were identified in vivo under a light microscope (Euromex Delphi-X, magnification between $\times 100-$ $\times 400$, mostly $\times 200$ ) using the guides of Schmelz and Collado (2010, 2012).

Juvenile specimens were not appropriate for identification (except for Buchholzia appendiculata (Buchholz, 1862)). Therefore, they were excluded from species composition analysis, but were reckoned in total enchytraeid density.

To measure soil moisture, further three samples were taken from each microplot (volume approximately $100 \mathrm{~cm}^{3}$ ). From each sample 40-60 g subsamples were taken to determine soil moisture by oven-drying $\left(105^{\circ} \mathrm{C}\right.$ for 48 hours).

Air temperature data were collected daily from the website of the Hungarian Meteorological Service (OMSZ). Precipitation was measured every day with a rain gauge (Figure 2).

\section{Data analysis}

The effects of the different mulch types on soil moisture and enchytraeids were investigated using linear mixed-effects models with Gaussian error structure (Faraway 2006). In the models, mulching treatment (four levels + control) was used as fixed factor, while plant individuals were treated as random term. Goodness-of-fit values of the models were measured by likelihood-ratio test-based coefficient of determination $\left(\mathrm{R}_{\mathrm{LR}}^{2}\right.$; Bartoń 2020), the explanatory power of the treat- 


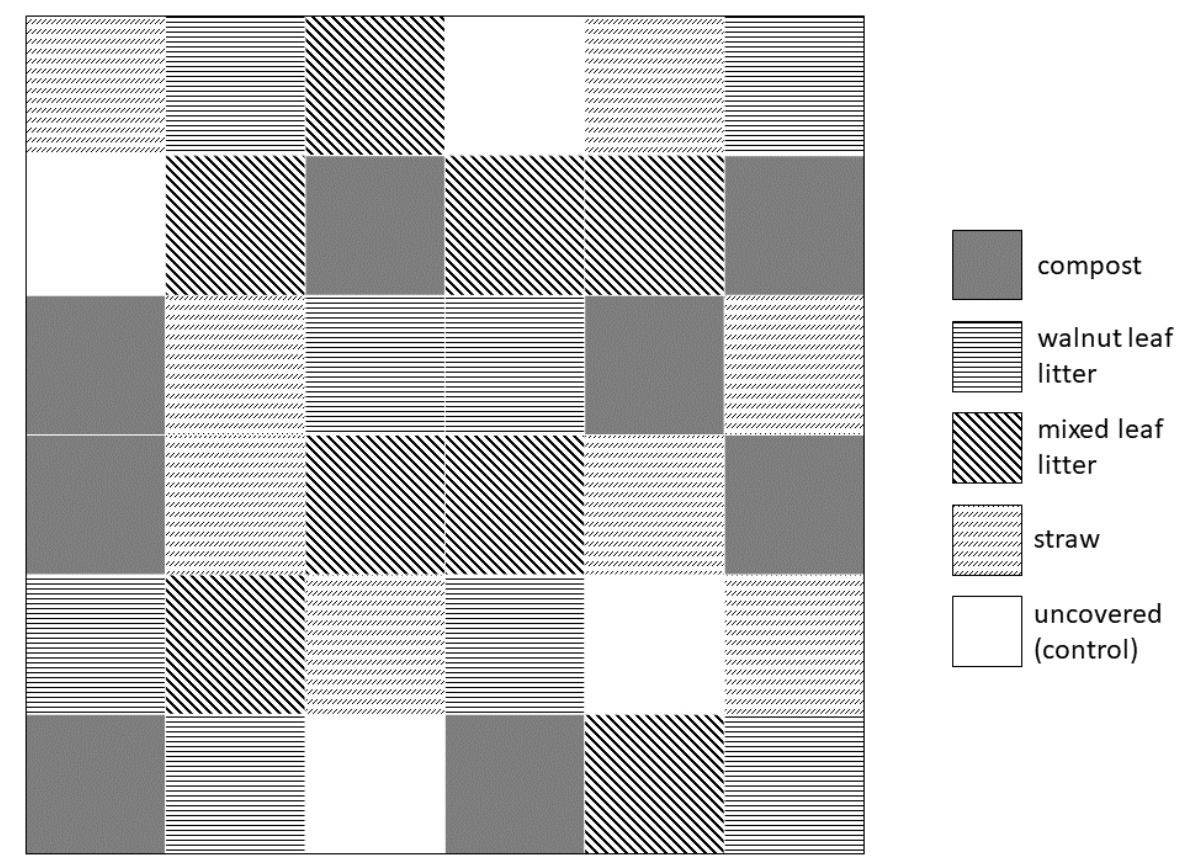

Figure 1. Arrangement of mulch treatments.

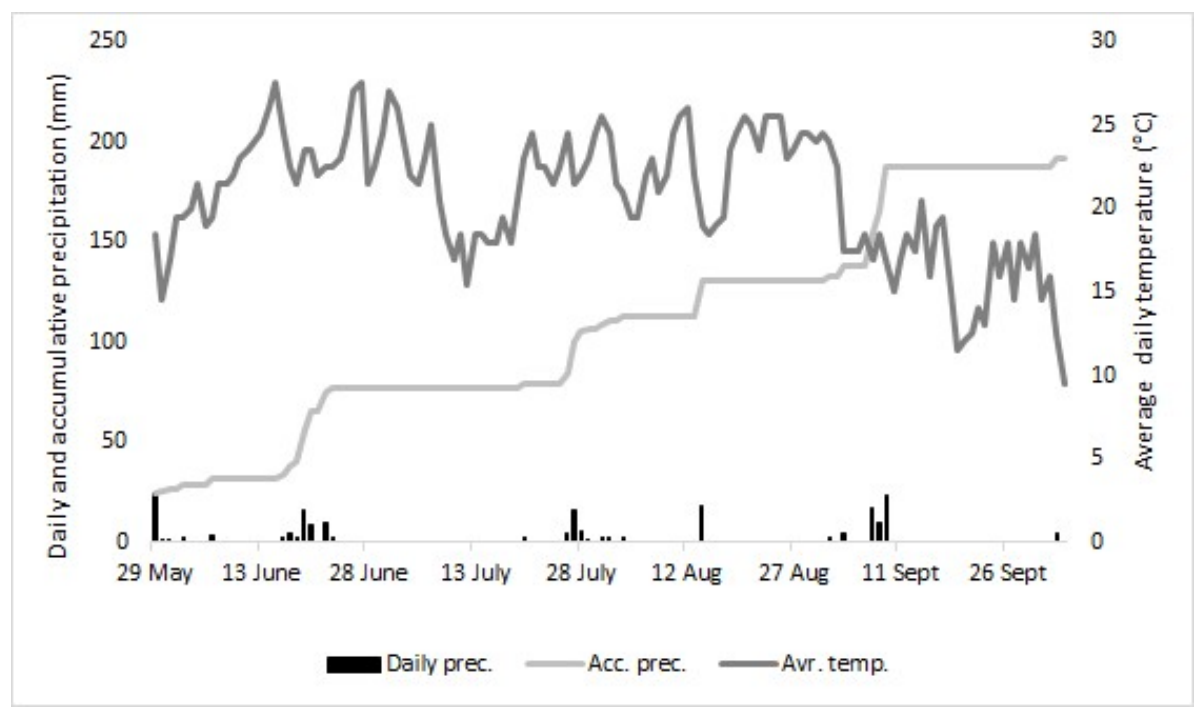

Figure 2. Average daily temperature, precipitation, and accumulative precipitation amount in the growing season of 2019.

ments was evaluated F-statistics (Faraway 2006). The differences between the treatment levels were tested using Tukey-type multiple comparisons procedure (using $\mathrm{p} \leq 0.05$ significance level) for all of the pairwise comparisons by general linear hypothesis tests
(Hothorn et al. 2008).

The effects of the treatments on species composition was explored by non-metric multidimensional scaling (NMDS) using Euclidean distance function and square root transformation of the abundance data (Borcard et al. 
2011). Moreover, permutational multivariate analysis of variance (PERMANOVA; Anderson 2001) based on Bray-Curtis dissimilarity with 9999 permutations was applied to measure the separation between the treatment types. The relationship between enchytraeids density and soil moisture levels was tested by Pearson product-moment correlation coefficient.

All analyses were made in $\mathrm{R}$ version 3.4.1 ( $\mathrm{R}$ core Team 2017). The GLMM of abundances was made by the "lme" function of "nlme" package (Pinheiro et al. 2017). The likelihood test based coefficient of determination was calculated by "r.squaredGLMM" function of "MuMIn" package (Barton 2016). Multiple comparisons of linear hypothesis test were made by "glht" function of "multcomp" package (Hothorn et al. 2008). NMDS were made by "metaMDS" function, PERMANOVA by the "adonis" function of "vegan" package (Oksanen et al. 2017).

\section{Results}

The total number of specimens, 236, belonged to six genera, 13 species:

Achaeta eiseni Vejdovský, 1878

Achaeta pannonica Graefe, 1989

Buchholzia appendiculata Buchholz, 1862

Enchytraeus buchholzi s.l. Vejdovský, 1879

Enchytraeus varithecatus Bouguenec \& Giani, 1987

Enchytronia parva Nielsen \& Christensen, 1959

Fridericia bisetosa Levinsen, 1884

Fridericia connata Bretscher, 1902

Fridericia galba Hoffmeister, 1843

Fridericia hegemon Vejdovský, 1878

Fridericia nemoralis Nurminen, 1970

Fridericia paroniana Issel, 1904

Marionina communis Nielsen \& Christensen, 1959

The most frequent species was E. buchholzi, which was found in all treatments with a relative abundance of $4.5-27.3 \%$. The second dominant species was $B$. appendiculata with $14.7-37.1 \%$ relative abundance; however, this species occurred only in walnut leaf litter, mixed leaf litter and straw microplots. $F$. paroniana had the highest abundance in walnut leaf litter samples (19.7\%) and the third highest in total $(10.5 \%)$, but in other samples, this species was subdominant. Only two specimens of $E$. varithecatus was found and only in straw-covered samples.

Walnut litter microplots contained 30.5\% of the total number of mature specimens, straw-covered microplots $30 \%$, mixed litter $17.5 \%$, and compost mulch and uncovered microplots both $11-11 \%$. The highest density was 19400 individuals $/ \mathrm{m}^{2}$ (mixed leaf litter), while there were three samples (in compost and control microplots) with no specimens (Table 1).

According to our models, mulch types had significant effects on density $\left(\mathrm{R}_{\mathrm{LR}}^{2}=0.25\right.$, $\left.\mathrm{F}_{(4,67)}=5.88, p=0.0004\right)$. Under walnut leaf litter, mixed leaf litter and straw cover, higher number of individuals was found than in the case of compost and uncovered microplots (Figure 3).

There was a significant separation among the treatments based on the performed PERMANOVA $\left(\mathrm{R}^{2}=0.28, \mathrm{~F}=1.96, p=0.0046\right)$. The NMDS (stress $=0.134$ ) revealed that the microplots of compost and uncovered had homogenous and slightly separated groups, while the treatments of walnut leaf litter, mixed leaf litter and straw were more heterogeneous as it is observable on the ordination diagram (Figure 4).

A strong treatment effect was observed on the soil moisture $\left(\mathrm{R}_{\text {LR }}^{2}=0.68, \mathrm{~F}_{(4,67)}=\right.$ $37.97, p<0.0001)$. Straw mulching had the highest soil moisture, in walnut and mixed leaf litter, soil water content was intermediate, while compost and uncovered surface induced the driest soil conditions (Figure 5).

Density and soil moisture were significantly correlated according to the Pearson correla- 
Table 1 . Density and soil moisture (mean $\pm \mathrm{SD}$ ) values in different treatments

\begin{tabular}{lcc}
\hline Treatment & $\begin{array}{c}\text { density (individual } / \mathrm{m}^{2} \text { ) } \\
\text { mean } \pm \mathrm{SD}\end{array}$ & $\begin{array}{c}\text { soil moisture }(\mathrm{m} / \mathrm{m} \%) \\
\text { mean } \pm \mathrm{SD}\end{array}$ \\
\hline compost & $2710 \pm 2150$ & $3.33 \pm 0.85$ \\
walnut leaf litter & $6380 \pm 3980$ & $3.56 \pm 0.70$ \\
mixed leaf litter & $6480 \pm 5290$ & $2.55 \pm 0.82$ \\
straw & $7780 \pm 3390$ & $4.56 \pm 1.08$ \\
uncovered (control) & $2110 \pm 2160$ & $2.52 \pm 0.75$ \\
\hline
\end{tabular}

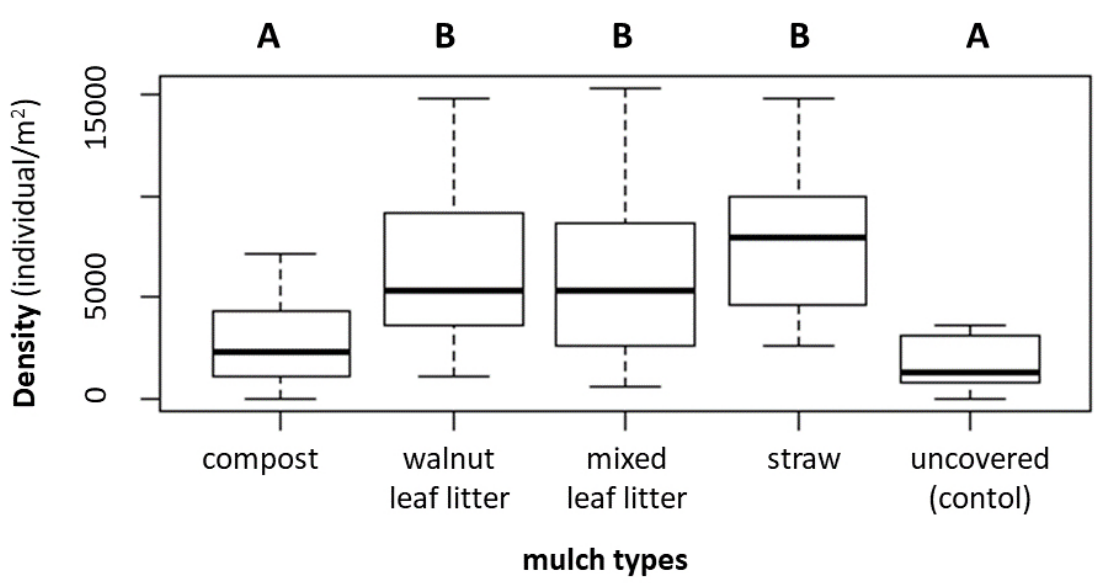

Figure 3. Boxplot of the enchytraeid density under different mulch types. Different letters indicate significant difference between means $(p \leq 0.05)$.

tion analysis $(r=0.38, \mathrm{p}$-value $=0.0009)$. In general, the density of enchytraeids increased by the higher values of soil moisture values of different treatments (Figure 6). However, 6480 individuals were counted at $2.55 \%$ soil moisture content under mixed leaf litter (Table 1).

\section{Discussion}

The enchytraeid density of microplots was found in fair accordance with soil moisture. The highest numbers of enchytraeids and the highest soil moisture were also observed under straw mulch. Since mycelial web in these microplots were observed and according to studies, enchytraeid communities contain $80 \%$ microbivorous and $20 \%$ saprovorous feeders (Didden 1993), so not only soil moisture but mycelia as a food source can increase their number under straw mulching. Walnut- and mixed leaf littercovered plots also had a significantly humid soil compared to control. Leaf litter also is considered to provide nutrients for enchytraeids, and the larger body size Fridericia 


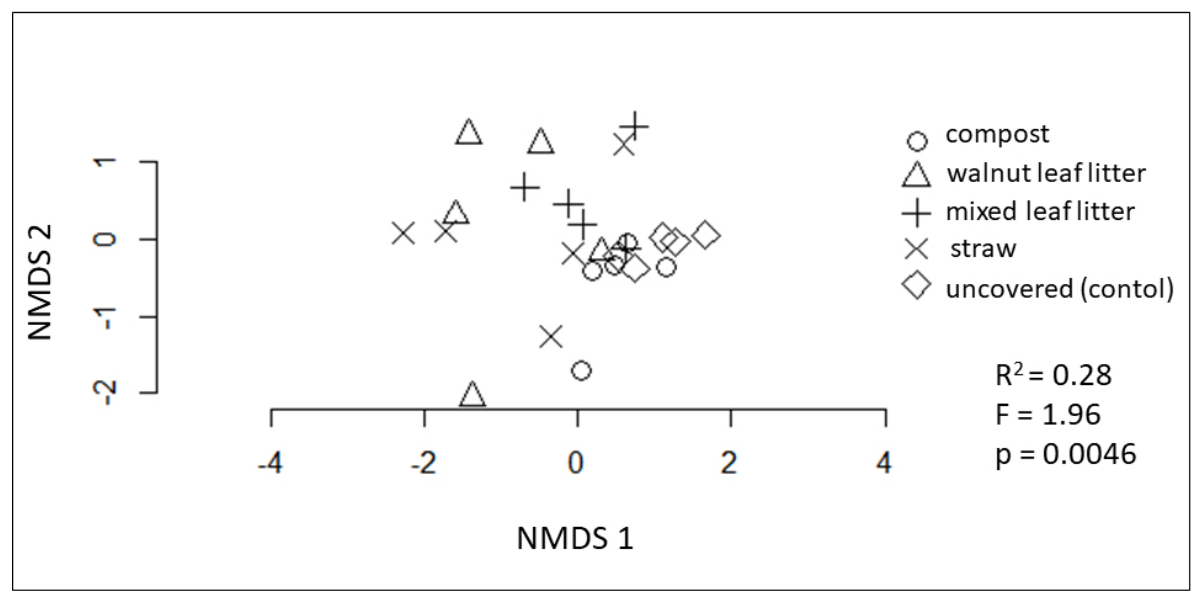

Figure 4. Non-metric multidimensional scaling ordination of the different mulch types based on the density of enchytraeid species. The compositional difference between treatments expressed as the results of the PERMANOVA $\left(\mathrm{R}^{2}\right.$ - coefficient of determination, $\mathrm{F}$ and $\mathrm{p}$ values) are portrayed on the panel.

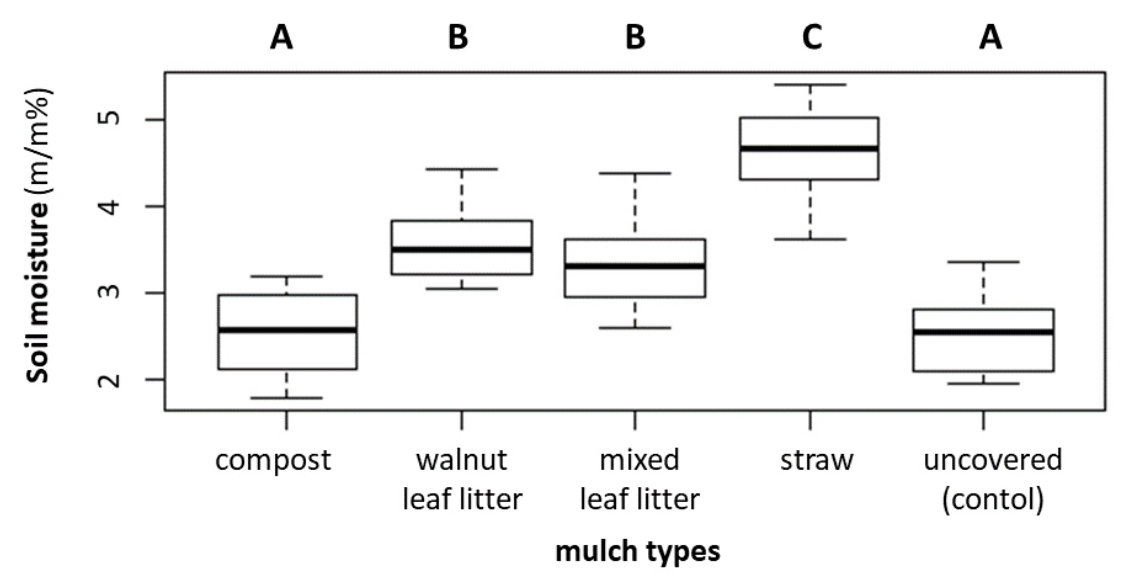

Figure 5. Boxplot of soil moisture under different mulch types. Different letters indicate significant difference between means $(p \leq 0.05)$.

species (e.g. F. hegemon, F. galba) prefer to Farkas 1976), which can be an explanation consume this kind of organic matter (Dózsa- for their high density. 


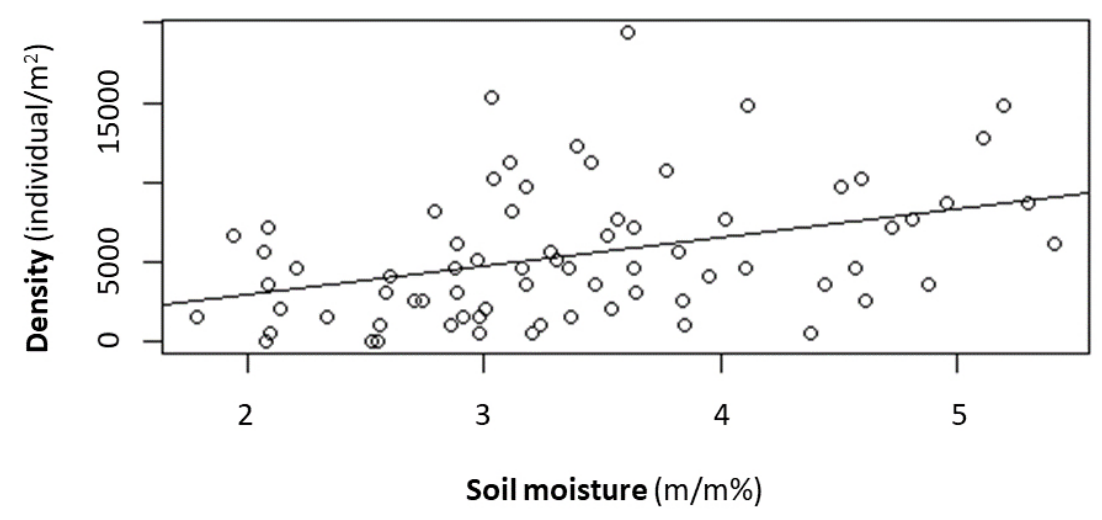

Figure 6. Correlation test (Pearson) between soil moisture and the density of enchytraeids in the soil samples.

The lowest number of enchytraeids was found in the control (uncovered) and compost-covered microplots. These treatments also had the lowest soil moisture content. Generally, compost is a drier mulch type than litter or straw. Furthermore, its black colour promotes a more intense and quicker warm-up. Our findings are in accordance with the study of Dózsa-Farkas (1977), who established that individuals of Fridericia galba perish more rapidly on higher temperatures correlated to lower soil moisture content than on lower temperatures.

Our soil moisture values under different mulch materials were quite low (between $2.52 \%$ and $4.56 \%$ ), which is considered a very dry soil condition. Among soil organisms, enchytraeids are sensitive to desiccation (Didden 1993). However, Maraldo and Holmstrup (2009) examined the effect of different drought events on enchytraeid populations. One of their treatments, artificial drought with only $5 \%$ soil water content was achieved on sandy soil, a condition, which was similar to our open-field condi- tions before sampling. While they did not find any Enchytraeid individual in May and June, however, between August and October, enchytraeid densities were higher than 10000 individuals per $\mathrm{m}^{2}$ in each month. They concluded that not only the moisture conditions at the time of sampling, but also moisture conditions in the past could have influenced the population of enchytraeids (Maraldo and Holmstrup 2009). This can explain the relatively high densities we found in dry conditions, since only $50 \mathrm{~mm}$ precipitation fell between 7 and 9 September, one month before sampling.

Besides mulching, avoidance of disturbance can also increase the number of enchytraeids. The abundance and biodiversity of soil macrofauna, in general, were significantly higher under no-till with mulch system than under conventional tillage (Brévault et al. 2007), while enchytraeid densities and biomass in the no-till system were significantly higher under no-till conditions (Parmelee et al. 1990, Fijuta and Fujiyama 2000). In general, mulch keeps the 
soil cooler and moist, which is an advantage not only for plants but for soil fauna as well. Mulch materials also contain nutrients for soil fauna, and consequently, enchytraeid communities prefer mulch-covered soil. Their presence has several beneficial effects on soil properties including structure, porosity, or organic matter content. Due to these coherent effects, mulching is beneficial in agricultural and horticultural production as well.

\section{Acknowledgements}

Authors thank the help of Ildikó Ványiné Surman (SZIU, laboratory work), Nándor Rózsa (SZIU, field work), Professor Gábor Bakonyi (SZIU, advices for the manuscript), Bence Kovács (Centre of Ecological Research, advices for the statistical analyses) and Franciska T. Bogdányi (language revision).

\section{References}

Addison, P., Baauw, A.H., Groenewald, G.A. (2013): An initial investigation of the effects of mulch layers on soil-dwelling arthropod assemblages in vineyards. South African Journal for Enology and Viticulture. 34: 2. 266-271. https://doi.org/10.21548/34-2-1104

Adekalu, K.O., Olorunfemi, I.A., Osunbitan, J.A. (2007): Grass mulching effect on infiltration, surface runoff and soil loss of three agricultural soils in Nigeria. Bioresource Technology. 98: 912-917. https://doi.org/10.1016/j.biortech.2006.02.044

Anderson, M.J. (2001): A new method for non-parametric multivariate analysis of variance. Austral Ecology 26: 32-46. https://doi.org/10.1111/j.1442-9993.2001.01070.pp.x

Andrén, O., Lagerlöf, J. (1983): Soil fauna (microarthropods, enchytraeids, nematodes) in Swedish agricultural cropping systems. Acta Agriculturae Scandinavica. 33: 33-52.https://doi.org/ 10.1080/00015128309435350

Barton, K. (2016): MuMIn: Multi-Model Inference. R package version 1.15.6.

Borcard, D., Gillet, F., Legendre, P. (2011): Numerical Ecology with R. Springer, New York. https://doi.org/10.1007/978-3-319-71404-2

Brévault, T., Bikay, S., Maldès, J.M., Naudin, K. (2007): Impact of a no-till with mulch soil management strategy on soil macrofauna communities in a cotton cropping system. Soil \& Tillage Research. 97: 140-149. https://doi.org/10.1016/j.still.2007.09.006

Brussaard, L., Aanen, D.K., Briones, M.J.I., Decaëns, T., De Deyn, G.B., Fayle, T.M., James, S.W., Nobre, T. (2012): Biogeography and Phylogenetic Community Structure of Soil Invertebrate Ecosystem Engineers: Global to Local Patterns, Implications for Ecosystem Functioning and Services and Global Environmental Change Impacts. In: Wall, D.H., Bardgett, R.D., Behan-Pelletier, V., Herrick, J.E., Jones, T.H., Ritz, K., Six, J., Strong, D.R., van der Putten, W.H. (eds.): Soil Ecology and Ecosystem Services. Oxford University Press Oxford. pp. 271-274. https://doi.org/10.1093/acprof: oso/9780199575923.003.0018

Dezsény, Z. (2015): Compost mulch no-tillage systems in organic vegetable production. Acta Fytotechnica et Zootechnica. 18: 138-141.

Didden, W. (1991): Population ecology and functioning of Enchytraeidae in some arable farming systems. Doctoral thesis. Agricultural University, Wageningen, Netherlands.

Didden, W.A.M. (1993): Ecology of Enchytraeidae. Pedobiology. 37: 2-29.

Domínguez, A., Bedano, J.C. (2016): Earthworm and enchytraeid co-occurrence pattern in organic and conventional farming. Soil Science. 181: 3/4. 148-156. https://doi.org/10.1097/SS.0000000000000146

Dózsa-Farkas, K. (1976): Über die Nahrungswahl zweier Enchytraeiden-Arten (Oligochaeta: Enchytraeidae). - Acta Zoologica Academiae Scientiarum Hungaricae. 22: 1-2. 5-28. 
Dózsa-Farkas, K. (1977): Beobachtungen über die Trockenheitstoleranz von Fridericia galba (Oligochaeta, Enchytraeidae). Opuscula Zoologica Budapest. 14: 1-2. 77-83.

Dudás, P., Gedeon, Cs., Menyhárt, L., Ambrus, G., Tóth, F. (2016): The effect of mulching on the abundance and diversity of ground beetle assemblages in two Hungarian potato fields. Columella - Journal of Agricultural and Environmental Sciences. 3: 45-53. https://doi.org/10.18380/ SZIE.COLUM.2016.3.1.45

Faraway, J.J. (2006): Extending the linear model with R. Chapman and Hall, London.

Fehér, A., Póss, A., Turóczi, Gy., Tóth, F. (2017): Különböző szerves talajtakaró anyagok talajlakó károsítókra gyakorolt hatásának vizsgálata burgonya tesztnövény segítségével. Növényvédelem. 78: 9. 399-404.

Forge, T.A., Hogue, E., Neilsen, G., Neilsen, D. (2003): Effects of organic mulches on soil microfauna in the root zone of apple: implications for nutrient fluxes and functional diversity of the soil food web. Applied Soil Ecology. 22: 39-54. https://doi.org/10.1016/S0929-1393(02)00111-7

Fujita, M., Fujiyama, S. (2000): Soil meso-fauna in two microenvironments of a no-tillage organic farming field. Edaphologia. 66: 11-20.

Goulet, E., Dousset, S., Chaussod, R., Bartoli, F., Doledec, A.F., Andreux, F. (2004): Waterstable aggregates and organic matter pools in a calcareous vineyard soil under four soil-surface management systems. Soil Use Manage. 20: 318-324. https://doi.org/10.1111/j.1475-2743.2004. tb00376.x

Hothorn, T., Bretz, F., Westfall, P. (2008): Simultaneous inference in general parametric models. Biometrical Journal. 50: 346-363. https://doi.org/10.1002/bimj.200810425

Jodaugienè, D., Pupalienė, R., Sinkevičienė, A., Marcinkevičienè, A., Žebrauskaitė, K., Baltaduonytė, M., Čepulienè, R. (2010): The influence of organic mulches on soil biological properties. Zemdirbyste-Agriculture. 97: 2. 33-40.

John, K., Degtyarev, M., Gorbunova, A., Korobushkin, D., Knöss, H., Wolters, V., Zaitsev, A.S. (2019): Enchytraeids simultaneously stimulate rice straw degradation and mitigate $\mathrm{CO}_{2}$ release in a paddy soil. Soil Biology and Biochemistry. 131: 191-194. https://doi.org/10.1016/j.soilbio.2019. 01.014

Kandel, S.L., Shrestha, S.M., Poudyal, D.S., Dahal, K.R. (2011): Effect of tillage, mulch and nitrogen management on soil microorganisms of rice-wheat cropping system in Nepal. Journal of the Institute of Agriculture and Animal Science. 32: 151-158.

Kasprzak, K. (1982): Review of enchytraeid (Oligochaeta, Enchytraeidae) community structure and function in agricultural ecosystems. Pedobiologia. 23: 217-232.

Langat, J.K., Kimenju, J.W., Mutua, G.K., Muiru, W.M., Otieno, W. (2008): Response of freeliving nematodes to treatments targeting plant parasitic nematodes in carnation. Asian Journal of Plant Sciences. 7: 467-472.

MacDaniels, L.H., Pinnow, D.L. (1976): Walnut toxicity, an un-solved problem. Northern Nut Growers Association Annual Report. 67: 114-122.

McSorley, R., Gallaher, R.N. (1995): Effect of yard waste compost on plant-parasitic nematode densities in vegetable crops. Supplement to the Journal of Nematology. 27: 4S. 545-549.

Maraldo, K., Holmstrup, M. (2009): Recovery of enchytraeid populations after severe drought events. Applied Soil Ecology. 42: 227-235. https://doi.org/10.1016/j.apsoil.2009.04.004

Nébih (2020): Termésnövelôk adatbázisa. [Crop enhancers database]. Available on: https:// termesnovelo.nebih.gov.hu/Engedelykereso/DocumentHandler.ashx?documentId=T343\&documentName= Szelekt\%c3\%advkomposzt2015.pdf

O'Connor, F.B. (1962): The extraction of Enchytraeidae from soil. In: Murphy, P.W. (ed.): Progress in Soil Zoology. Butterworths, London, pp. 279-285.

Oksanen, J., Blanchet, F.G., Friendly, M., Kindt, R., Legendre, P., McGlinn, D., Minchin, P.R., O’Hara, R.B., Simpson, G.L., Solymos, P., Henry, M., Stevens, H., Szoecs, E., Wagner, H., 
2017. vegan: Community Ecology Package. R package version 2.4-4.

Parmelee, R.W., Beare, M.H., Cheng, W., Hendrix, EF., Rider, S.J., Crossley Jr., D.A., Coleman, D.C. (1990): Earthworms and enchytraeids in conventional and no-tillage agroecosystems: A biocide approach to assess their role in organic matter breakdown. Biology and Fertility of Soils. 10: $1-10$.

Petrikovszki, R., Zalai, M., Tóthné Bogdányi, F., Tóth, F. (2020): The effect of organic mulching and irrigation on the weed species composition and the soil weed seed bank of tomato. Plants. 9: 1. 66. https://doi.org/10.3390/plants9010066

Pinamonti, F. (1998): Compost mulch effects on soil fertility, nutritional status and performance of grapevine. Nutrient Cycling in Agroecosystems. 51: 239-248.

Pinheiro, J., Bates, D., DebRoy, S., Sarkar, D., R Core Team (2017): nlme: Linear and Nonlinear Mixed Effects Models. R package version 3.1-131.

Pupalienè, R., Sinkevičienè, A., Jodaugienè, D., Bajorienè, K. (2015): Weed control by organic mulch in organic farming system. In: Pilipavicius, V. (ed.): Weed Biology and Control. InTech: Rijeka, Croatia, pp. 65-86. http://dx.doi.org/10.5772/60120

R Core Team (2017): R: A language and environment for statistical computing. R Foundation for Statistical Computing, Vienna, Austria. URL https://www.R-project.org/.

Ricci, F., Bentze, L., Montagne, D., Houot, S., Bertrand, M., Pelosi, C. (2015): Positive effects of alternative cropping systems on terrestrial Oligochaeta (Clitellata, Annelida). Soil Organisms. 87: 2. 71-83.

Schmelz, R.M., Collado, R. (2010): A guide to European terrestrial and freshwater species of Enchytraeidae (Oligochaeta). Soil Organisms 82: 1-176.

Schmelz, R.M., Rut Collado, R. (2012): Guide to European Terrestrial and Freshwater Species of Enchytraeidae (Oligochaeta): First supplement. Newsletter on Enchytraeidae 12: 53-66.

Stefanovits, P., Filep, Gy., Füleky, Gy. (1999): Talajtan. Mezőgazda Kiadó, Budapest.

Südiné Fehér, A., Erdôs, E., Tóthné Bogdányi, F., Turóczi Gy., Tóth, F. (2019): Metarhizium anisopliae és Trichoderma asperellum kölcsönhatásának vizsgálata laboratóriumi és szabadföldi körülmények között. [Interaction between Metarhizium anisopliae and Trichoderma asperellum in laboratory and open field experiments]. Növényvédelem. 80: 7. 295-303.

Summers, D.A., Lussenhop, J. (1976): The response of soil arthropods to canopies of black walnut. Pedobiologia. 16: 389-395.

Thomson, L.J., Hoffmann, A.A. (2007): Effects of ground cover (straw and compost) on the abundance of natural enemies and soil macro invertebrates in vineyards. Agricultural and Forest Entomology. 9: 173-179. https://doi.org/10.1111/j.1461-9563.2007.00322.x

van Vliet, P.C.J., Hendrix P.F. (2012): Soil Fauna: Enchytraeidae-Oligochaeta. In: Huang, P.M., Li, Y., Sumner, M.E. (eds.): Handbook of Soil Sciences: Properties and Processes, Second Edition. CRC Press, Taylor \& Francis Group. pp. 25-26-25-35.

Xiao, Z., Liu, M., Jiang, L., Chen, X., Griffiths, B.S., Li, H., Hu, F. (2016): Vermicompost increases defense against root-knot nematode (Meloidogyne incognita) in tomato plants. Applied Soil Ecology. 105: 177-186. https://doi.org/10.1016/j.apsoil.2016.04.003 
